\title{
Helping Refugees Where They Are Mollie Gerver
}

Immigration and Freedom, Chandran Kukathas (Princeton, N.J.: Princeton University Press, 2021), 384 pp., cloth \$35, eBook \$35.

The Wealth of Refugees: How Displaced People Can Build Economies, Alexander Betts (Oxford: Oxford University Press, 2021), 448 pp., cloth \$25.95, eBook \$17.99.

The Ethics of Migration: An Introduction, Adam Hosein (New York: Routledge, 2019), 214 pp., cloth $\$ 160$, paperback \$44.95, eBook \$44.95.

Illegal: How America's Lawless Immigration Regime Threatens Us All, Elizabeth F. Cohen (New York: Basic Books, 2020), 272 pp., cloth \$28, eBook \$16.99.

I magine that an aid worker in Jordan is deciding whether to help a Syrian refugee obtain resettlement in Canada. She has no duty to try and resettle this refugee if the Canadian government will certainly not accept him. Or imagine that a refugee is seeking safety. He has no duty to wait for a visa that no state will ever provide; he is permitted to pay a smuggler to cross a border, given states' policies. Finally, imagine that a member of parliament (MP) is considering whether her country should admit more Afghan refugees. She has no duty to continue advocating for refugee resettlement if her coparliamentarians will block any legislative attempts to do so. In each of these instances, we see that one's duties depend in part on how others will act.

If we assume that one's duties are impacted by others' actions, then sometimes an individual has a duty to advance the interests of the powerful to ensure certain policies are feasible to pursue. For example, the above MP might justifiably

Mollie Gerver, University of Essex, Colchester, England (m.gerver@essex.ac.uk)

Ethics \& International Affairs, 35, no. 4 (2021), pp. 563-580.

(c) The Author(s), 2021. Published by Cambridge University Press on behalf of the Carnegie Council for Ethics in International Affairs. This is an Open Access article, distributed under the terms of the Creative Commons Attribution licence (https://creativecommons.org/licenses/by/4.o/), which permits unrestricted re-use, distribution, and reproduction in any medium, provided the original work is properly cited.

doi:10.1017/So892679421000575 
propose sending aid to Afghan refugees in Pakistan to deter them from attempting to reach Europe, because it is in her coparliamentarians' interests to support aid that deters inward migration-an effect that will help their reelection. These other parliamentarians may be acting wrongly in only supporting aid abroad and not resettlement, but if their minds cannot be changed, the MP in question may be justified in focusing on policies her colleagues would endorse.

Alexander Betts's The Wealth of Refugees takes seriously what people, institutions, and states ought to do given the actions of other people, institutions, and states. He argues that those who care about refugees should support policies protecting refugees' rights-including their rights to economic development and basic necessities-but that such policies are only feasible if consistent with the interests of powerful actors in higher- and lower-income states. These powerful actorsincluding heads of states, parliamentarians, and local mayors-often place constraints on what policies are possible, as when policymakers in wealthy states simply refuse to admit more refugees. Their actions may not always be ethical, and the power that many of these actors hold may be unjust, but if they continue to hold such power into the near future, then policies will only be feasible with their support. In other words, there are certain facts about the world that we cannot change soon, and so if we are to operate within the bounds of political reality, policies are only feasible if compatible with a range of policymakers' interests.

In wealthy states, argues Betts, policymakers' interests are often to deter inward migration and eventually reduce aid abroad. If so, the most politically feasible policy to help the vast majority of refugees is to develop the economies where they currently reside.

In the following section, I describe Betts's claims in greater detail. I then draw on three recent works on immigration-books from Elizabeth F. Cohen, Chandran Kukathas, and Adam Hosein-to offer a critique of his position.

\section{The Case for Helping Refugees Where They Are}

Betts first demonstrates that some policy proposals favored by refugee activists, such as admitting greater numbers of refugees into wealthy states, are unlikely to ensure long-term protection. In today's world, many politicians in wealthy states mobilize voters affected by austerity and the loss of manufacturing jobs, blaming immigrants for their problems. As a result, there is little political incentive for politicians to admit more refugees, and no political will to do so. Thus, 
humanitarian organizations cannot aid most refugees by helping them to obtain resettlement to wealthy states, as these states will not admit them (p. 22). This is especially true if we view refugees as including all "survival migrants" (p. 37), those migrating to avoid hunger, natural disasters, and general violence: there are potentially hundreds of millions of such individuals (Hosein, p. 119) and resettlement for most of them is politically infeasible.

Given the political infeasibility of mass resettlement for most refugees-and for simplicity, I assume that "refugees" includes all survival migrants-the focus ought to shift to improving the economies of low- and middle-income countries where most refugees reside: most Afghan refugees are in Pakistan and Iran; most Syrian refugees are in Turkey and Lebanon; and most South Sudanese refugees are in Uganda and Ethiopia. The economic rights of these refugees and their access to a range of necessities can be protected if wealthy states send aid to help them in their current countries of residence.

Not all aid, however, will be supported by wealthy states or effective when reaching poorer states. Drawing on novel data gathered in East Africa, Betts argues that aid will only be provided and effective if certain conditions are met. Among the conditions that Betts lays out are the following:

1. For aid to be effective, refugees must be given the right to move and work in lower-income host states.

2. For aid to be supported, it must be given in a way that helps the citizens in lower-income host states, as public opposition in these states can undermine the willingness of the government to protect refugees' rights.

3. More generally, aid will only be supported if consistent with the interests of powerful actors in lower-income and wealthy states, including the latter's interests in limiting migration and eventually discontinuing aid.

4. For aid to be both effective and supported in the long term, it must also improve the macroeconomic conditions of the regions hosting refugees, creating a strong export economy that improves the welfare of both refugees and citizens (pp. 349-53). This is important both because wealthy states may be reluctant to give aid that is not effective in the long term, and because long-term improvement of macroeconomic conditions ensures that refugees are not dependent on aid that may ultimately be discontinued.

What these conditions emphasize is that sustainability requires not only a good plan but one that can be implemented in practice (p. 228). Understanding what 
can be implemented requires understanding local and international contexts, including what interests are at stake and who exercises power. This, in turn, requires drawing on empirical data. Empirical data can provide evidence of not only what is politically feasible but also which politically feasible policies are most effective at protecting refugees' rights. If protecting refugees' rights is a central goal that aid agencies ought to pursue, these agencies ought to familiarize themselves with data on refugees, including findings from social science.

Social science is central to Betts's book, which includes an original data set based on survey responses from sixteen thousand refugees and nonrefugee citizens living in or around three sets of camps and urban centers, including Nakivale and Kampala in Uganda; the Dolo Ado camps and Addis Ababa in Ethiopia; ${ }^{1}$ and Kakuma, Kalobeyei, and Nairobi in Kenya. These locations were selected to compare urban and rural settings, and to compare three countries that differ in their official refugee policies: Uganda legally permits refugees to move throughout the country and work, Ethiopia is slowly permitting some refugees to move and work, and Kenya tightly constrains refugees' movement and work (pp. 75-77). These countries also differ in policy implementation, with Ethiopia officially open to granting work visas to more refugees but the local governments preventing such rights in practice, and Kenya officially against granting work visas to more refugees but the local governments permitting such rights in practice. While the data set does not represent all refugees in these countries, it is fairly representative of those living in the camps and urban locations selected: respondents were selected either randomly, as in Addis Ababa (p. 78), or using more complex twostage cluster sampling, as in Kakuma (p. 79).

The findings from this research are exceptionally detailed, including findings of policy failures. For example, the book describes the Kalobeyei settlement, where South Sudanese refugees were provided cash-based grants, entrepreneurship training, and gardens to grow food. Two years later, only 6 percent had an incomegenerating activity and less than 2 percent regarded themselves as being independent from aid (pp. 145-51). Aid from private foundations can also have limited long-term effectiveness, as seen in the findings from the Dolo Ado camps in Ethiopia. The camps received $\$ 100$ million from the IKEA Foundation to assist roughly twenty-two thousand refugees and Ethiopian citizens. The funding was used to create irrigation canals for one thousand hectares of land, subsidize livestock and dairy cooperatives, provide microfinance to over five hundred borrowers, and create solar panels and briquettes out of waste (p. 170). Despite these 
investments, the program has resulted in only 21 percent of the targeted community having access to employment, with those employed making an average of less than $\$ 1$ a day. Importantly, the largest employers are humanitarian organizations. Humanitarian organizations may leave if aid ever dries up, and so dependence on these organizations will do little to help refugees in the long term (p. 171).

The book does not merely present failures; it explains success stories and the lessons they hold as well. For example, in Dolo Ado women received solarpowered refrigeration to form dairy cooperatives. They then used the cooperative's savings to offer three months paid maternity leave to members (pp. 187-88). In Kalobeyei, South Sudanese refugees who were given employment rights and cash assistance were better fed than South Sudanese refugees in neighboring Kakuma, who arrived at roughly the same time but received neither benefit. Importantly, refugees in Kalobeyei became more independent from aid compared to South Sudanese refugees in Kakuma (p. 159).

Betts argues that these successes show that aid must shift to a "developmentbased approach," meaning aid must be used to develop the economies within which refugees live. In particular, there must be a large initial investment of aid to:

1. improve security, so that refugees can safely engage in income-generating activities;

2. ensure enforcement of contracts, so that refugee-owned firms can thrive;

3. implement anticorruption policies, so that transaction costs are lower; and

4. provide public goods such as education, infrastructure, and macroeconomic management (pp. 303-4).

While these plans might seem ambitious, they are possible to implement with the help of actors able to broker agreements between national and local governments. For example, the governor of Turkana County in Kenya, Josphat Nanok, managed to work with the Kenyan national government and donor states to draw in aid and improve legal rights for refugees, while UN Refugee Agency (UNHCR) country representative Clementine Nkweta-Salami in Addis Ababa managed to overcome bureaucratic hurdles to replace ineffective staff members, improving the efficiency of development projects in Dolo Ado. These and other individuals know how to appeal to the interests of wealthy states, such as by arguing that improving public goods in Africa can deter onward migration to Europe, and know how to appeal to the interests of local citizens, such as by arguing that investment in refugee- 
hosting regions can create jobs for citizens. Such individuals ought to be supported by UNHCR to further build partnerships, given the importance of improving the economies where most refugees reside (p. 305).

In short, Betts argues that:

1. Those who care about refugees should promote politically feasible policies that protect most refugees' rights in the long term.

2. Due to lack of political will, admitting refugees to wealthy countries is not a politically feasible solution for protecting most refugees' rights in the long term.

3. Under the right conditions, a development-based approach involving aid to refugees in lower-income countries is a politically feasible way to improve most refugees' rights in the long-term.

4. Therefore, policies involving aid to refugees in lower-income countries ought to be promoted.

Betts convincingly defends the first premise with philosophical argumentation, and he defends the third premise with extensive data. Importantly, he defends the third premise not only using examples from East Africa but also from Jordan and Colombia, drawing on preliminary data to demonstrate the possibility of a development-based approach in these countries (pp. 321-34).

Though the first and third premises are well-defended, the second premise rests on shakier grounds.

Betts defends the second premise by arguing that anti-immigrant policies in wealthier countries are a response to broader changes that are nearly impossible to counteract in the short term. In particular, falling real wages in these countries have caused widespread frustration among citizens and, in response, savvy politicians have promised to curtail immigration, providing an easy scapegoat for a more complex problem. This makes large-scale resettlement of refugees to rich countries unlikely (p. 31). Betts writes:

The only way in which large-scale resettlement . . could be created would be if citizens were persuaded on a large-scale that it was the morally right thing to do; and, while not impossible, everything we know about contemporary refugee politics suggests this is unlikely. (p. 49)

Here is a problem with the above defense: while citizens are unlikely to accept large-scale resettlement, they might accept reductions in immigration 
enforcement, resulting in significantly more refugees arriving and remaining. They might support such a policy not only because it is morally right but for selfinterested reasons as well.

\section{Flipping the Script on Immigration Enforcement}

To understand these reasons, consider arguments made in three recent books.

The first, Elizabeth F. Cohen's Illegal, addresses the harms of U.S. immigration enforcement, including harms to citizens. Two-thirds of U.S. citizens live within a "border region" where immigration agents can arrest and detain individuals without a warrant and without reasonable cause: If you "look Mexican" or simply are speaking Spanish, that is enough to be legally stopped (pp. 47-50). If you are stopped, you can be detained and deported without having seen a lawyer, even if you can afford one, and sometimes after only a sixty-second trial (pp. 5862). Not only have at least a million U.S. citizens been deported since 1930 (Kukathas, pp. 51 and 76), but millions today lack proper documentation of their citizenship, with thousands detained annually. For example, between 2005 and 2017 an estimated 3,506 U.S. citizens were detained in Texas alone (Cohen, pp. 26-27). Beyond these risks, immigration enforcement is expensive (and paid for by citizens' tax dollars). The budget for U.S. immigration enforcement reached almost $\$ 15$ billion in 2019 alone, more than the budget for all other enforcement agencies combined (p. 182). The opportunity costs are even higher. According to one study, the U.S. economy would be roughly $\$ 1.4$ trillion wealthier if undocumented immigrants were regularized (p. 196).

Importantly, Cohen argues that the interests of many U.S. citizens are not in line with the power of U.S. Customs and Border Protection (CBP). She describes the torture inflicted by CBP agents, including against U.S. citizens, and the complete lack of accountability for such actions. Even if a given U.S. citizen is not ultimately targeted, there is always the threat of being targeted. Worryingly, the actual odds of being targeted are unknown; the CBP does not release the number of U.S. citizens wrongly detained, tortured, and/or deported, and has generally weak internal reporting requirements for misconduct and fraud. This is particularly harmful for the 42.2 percent of Americans who are non-White, given the use of racial profiling, but all citizens without proof of citizenship are at risk of deportation (pp. 70-71). Even if most Americans do not fear deportation, the lack of transparency harms all citizens in a more subtle way: it undermines their ability 
to know what their government and its agencies do. This, in turn, makes it difficult for all citizens to hold immigration agencies accountable when they break the law. If the rule of law is something most citizens have an interest in upholding, then most citizens are harmed by today's policies (pp. 24 and 68-69).

Cohen's argument primarily concerns migrants arriving to the United States from Latin America, and the effects of immigration enforcement on U.S. citizens. In many regards, this topic is far removed from Betts's discussion of East African refugees. However, his general claims are relevant here: he argues that countries like the United States are unlikely to accept a major increase in refugees in general, and this justifies a focus on investing aid in a range of middle- and lower-income countries, including in Latin America (Betts, pp. 321-34). Cohen's analysis indirectly suggests otherwise. If most Americans have a personal interest in discontinuing current immigration enforcement for the reasons she suggests, and these enforcement practices are central reasons many refugees cannot live in the United States, most Americans might have an indirect interest in admitting many more refugees.

For example, hundreds of thousands of migrants are detained or deported each month by CBP. With one million predicted to enter the United States in 2021 alone, most of them will be deported if the current rates of deportation continue. ${ }^{2}$ Moreover, most of those deported will likely be refugees in the moral sense of lacking basic rights in their home countries. Those who are escaping malnutrition are not necessarily refugees according to international law, and those surviving domestic violence are not necessarily refugees according to U.S. law, but both groups have a moral right to cross borders and enter the United States if they have no other options for survival. ${ }^{3}$ Importantly, many are refugees in the legal sense of fleeing persecution because of their ethnicity, political views, religions, or social identities. ${ }^{4}$ Such individuals have legal rights to enter and remain, but CBP regularly fails to inform them of their rights, deporting them before they have a chance to apply for asylum (Cohen, pp. 200-201). If hundreds of thousands of people are deported annually by CBP, even an incremental curtailing of the agency's power and funding could result in far more refugees entering and remaining in the United States. Moreover, a decrease in enforcement may lead to more irregular migrants being able to work and access nominal rights in some cities, and potentially permanent residency after some time has passed. This is particularly true for those who are refugees according to U.S. law, but may even be true for 
survival migrants without current legal protections, who may eventually be given the right to remain.

If this sounds unrealistic, consider chapter 3 of Cohen's book, which describes widespread support for mass migration into the United States from Latin America during the 1920s. This support was strong along the Southern border, where many citizens viewed themselves as racially superior to migrants but nonetheless supported keeping the border with Mexico open. This was in their interests, as 98 percent of agricultural workers in the border region arrived from Mexico (p. 109). Importantly, citizens did not merely support mass migration on the condition that migrants eventually return or remain permanently without rights; they supported permitting unauthorized migrants to obtain a pathway to citizenship after living in the United States for three years, assuming they had not committed a crime. While this policy was enacted into federal law alongside the eugenics-inspired 1924 National Origins Act, which imposed race-based quotas on immigration, these quotas did not apply to migrants from the American continent, and so all of those entering through the open Southern border could qualify for citizenship if they remained. Cohen notes that Americans had self-interested reasons for implementing this policy: to retain desirable immigrants, the government needed to know who people were, which was far easier if all of them were given legal residency (pp. 100-101). A version of this regularization policy continued until the 1980 os and could today be reenacted alongside a less militarized Southern border; if even in the 1920 s white supremacists supported an open border and regularizing migrants, it seems plausible that Americans today could be persuaded to adopt this policy as well (p. 194). ${ }^{5}$ If, as I have argued, we accept that most migrants irregularly crossing the U.S.-Mexico border today can be broadly termed refugees, enacting such a policy could lead to many more refugees entering and remaining in the United States.

Some might argue that this policy would only help some refugees, especially if we accept a broad understanding of who counts as a refugee. As already noted, there are potentially hundreds of millions of individuals whose basic needs are not met in their home countries (Hosein, p. 119), and so millions entering the United States would be a small percentage of all those requiring asylum. Worryingly, many attempting to arrive die during their journeys, ${ }^{6}$ and those most likely to arrive safely are relatively privileged, able to afford transportation and smuggling fees. Indeed, Betts briefly discusses the possibility of simply 
allowing more refugees to migrate, and notes that due to the difficulties and costs of these journeys this would not be "equal, principled, or consistent" (Betts, p. 43).

While the above worries are legitimate, some would be made less serious if immigration enforcement were dramatically curtailed. Immigration enforcement is itself responsible for many dangers refugees face during journeys and for the high cost of smugglers and transport. ${ }^{7}$ For example, President Bill Clinton's Operation Gatekeeper turned migrants back at the border near San Diego, resulting in approximately seven thousand migrants dying while attempting to enter the United States through dangerous desert crossings (Cohen, p. 163), and resulting in migrants paying smugglers higher fees for more difficult routes. ${ }^{8}$ If reduced enforcement lowers the cost of migration, this would permit relatively less privileged refugees to seek safety in wealthier countries. Moreover, even if most refugees could never afford to reach wealthy states, not all refugees must reach wealthy states for the impact to be profound. If millions more refugees could obtain residency under a policy of reduced enforcement, and they sent remittances back to lower-income host states, the impact on refugees in lower-income countries could be significant.

This general claim can be extended beyond the American context addressed in Cohen's book. Some of the disadvantages of enforcement arise in other wealthy states as well, giving citizens there reasons to oppose enforcement preventing refugees from arriving, remaining, and sending remittances back to lower-income countries. For example, if enforcement were significantly reduced in Europe, this would lower the costs for Eritrean and South Sudanese refugees arriving there, increasing the number of refugees who could enter and send remittances back to Uganda, Kenya, and Ethiopia.

This broader claim relates to another recent book, Chandran Kukathas's Immigration and Freedom. Like Cohen, Kukathas argues that enforcement harms citizens, but focuses attention globally; in particular, he focuses on ways enforcement undermines freedom. For example, in certain countries if a citizen falls in love with an immigrant who is subject to deportation, he or she lacks the freedom to live with and start a family with this immigrant. Even when the couple is permitted to do so, this sometimes entails especially denigrating treatment: in the 1970s, the U.K. had a policy of "virginity testing" for Indian women arriving with the intention to marry British citizens. For women who sought visas that allowed them to marry once in the country, the tests were given on the premise that those who were not virgins must have already been 
married, and so were lying on their visa applications (Kukathas, p. 119). The women were of course the primary victims, but their fiancées were indirectly harmed by a policy whose implementation sexually violated the rights of those they loved and violated the privacy rights held by the couple more generally. Although this policy was discontinued by 1980, many U.K. citizens and their loved ones continue to be harmed by immigration enforcement. For instance, roughly eighteen thousand British citizens are unable to live with their family members each year because of a law requiring citizens to make a certain amount of money before their family members are admitted into the country (p. 66).

Kukathas shows how enforcement can even constrain citizens' freedoms in more direct ways, as when citizens are stopped on the streets and sometimes deported, including (as mentioned above) over a million deported from the United States since 1930 (pp. 51 and 76). Enforcement also curtails economic freedoms. In a range of countries, migrants cannot join labor unions and are forced to accept lower wages, undercutting citizens' own bargaining power and wages (pp. 51-61). Citizens are additionally prevented from hiring a range of migrants to perform certain jobs (p. 139), including jobs that often create more jobs for citizens, as when a firm stays afloat due to migrant labor and can hire citizens as a result (p. 146). Preventing migrants from arriving and working can also be detrimental to working mothers. For example, because Japan severely limits immigration, there are not enough childcare providers to meet demand, resulting in Japanese women leaving the workforce at high rates, limiting women's opportunities and slowing economic growth (p. 141).

Finally, enforcement curtails freedom of information. For example, the Australian government conceals conditions in offshore detention centers, with journalists blocked from entering these centers to report on beatings and sexual assaults taking place (pp. 237-38). Like Cohen, Kukathas argues that this not only harms those subjected to abuse but also undermines the freedom of all citizens to access information on what their government does. The government's ability to control how information is released can also normalize these abuses, creating an apathy on the part of citizens (p. 123 and pp. 239-40). The Australian government's implication that refugees are criminals can cause citizens to accept abuses as normal, or at least ethically ambiguous, reducing the will to protest. This results in violations of refugees' rights and citizens' interests: it costs taxpayers $\$ 345,000$ a year per detainee, far more than it would cost citizens to permit refugees to work and live freely on Australian territory (p. 238). 
Kukathas argues against the idea that governments could reform rather than reduce immigration enforcement, avoiding infringing on citizens' freedoms while still limiting inward migration (p. 68). He shows that even with such reforms, governments seeking to admit fewer migrants will necessarily run counter to many citizens' interests in admitting more migrants, including citizens attempting to live with, speak with, worship with, and employ unauthorized migrants. For example, if citizens seek to hire unauthorized migrants, then the sanctions on citizens who attempt to do so must be significant for enforcement to be effective. "The more control is sought," writes Kukathas, "the greater will be the loss of freedom" (p. 68). The flip side is that the more freedom is demanded by citizens, and the more governments increase citizens' freedoms, the less control the government has in blocking migrants from arriving and remaining (pp. 6769). Assuming citizens have an interest in protecting their freedoms, they have an interest in supporting policies that lead to the admissions of far more migrants, including refugees.

The above claims focus on freedom: the freedom to know what the government does and the freedom to hire, live with, and interact with immigrants. There are more subtle ways that citizens have an interest in reduced enforcement. In The Ethics of Migration, Adam Hosein notes that enforcement often targets migrants practicing particular religions, speaking particular languages, having particular sexualities, or coming from particular nations and/or ethnicities. Citizens who share these religions, languages, sexualities, nationalities, or ethnicities are often offended when noncitizens are targeted because of these characteristics. Versions of this claim have previously been made by others, ${ }^{9}$ but Hosein notes that even when there is no proof that citizens have been targeted because of the aforementioned characteristics, sometimes it can be reasonable to presume they have been. In such cases, it can be morally justified for citizens to oppose such practices. For example, when thousands of immigrants from Latin America are rounded up and deported from the United States, but white-presenting European migrants are not, it could be that the migrants who are deported just happen to be Latino, but a Latino citizen can reasonably interpret this as disproportionately targeting Latino migrants as compared to other migrants. This can therefore cause reasonable offense (pp. 75-76; pp. 85-87; p. 98; and p. 194). This, in turn, can explain some of the growing opposition to immigration control in the United States by many Latino citizens, including opposition to the deportation of hundreds of thousands of asylum seekers arriving annually. The 
opposition is not just because citizens think they have moral duties toward refugees; they feel wronged themselves. ${ }^{10}$

In explaining why they feel wronged, Hosein draws on the work of José Mendoza and Amy Reed-Sandoval, ${ }^{11}$ who note that enforcement that targets individuals holding particular characteristics can lead to citizens with these characteristics feeling like only partial citizens, or like their characteristics indicate a lower social status. This is particularly true if citizens with these characteristics are regularly stopped by enforcement agents and private citizens suspicious of their right to live in the country. Such citizens can be termed, to use Reed-Sandoval's term, "socially undocumented." ${ }^{12}$ This can create weighty reasons to discontinue a range of enforcement practices. For example, as noted in the discussion of Cohen's book, the CBP can legally stop individuals if they are speaking Spanish and quickly detain them if they lack documentation proving their citizenship. This practice might genuinely decrease the number of unauthorized migrants remaining in the United States, but such a policy might be considered unjustified by virtue of its effects on citizens. If discontinued on the basis of its lack of justification, this might lead to an increase in the number of refugees who can ultimately remain in the United States.

In short, there are plenty of reasons citizens in wealthy countries could be persuaded to dramatically increase the number of refugees living within their countries. They can be persuaded by appealing not only to their moral obligation to admit refugees but also to their various self-interested reasons to experience less enforcement. If enough citizens demand much weaker enforcement, policymakers may feel pressure to respond to citizens' demands and increase the number of refugees admitted.

Importantly, this phenomenon can arise even if most citizens do not feel particularly badly off from current enforcement practices. So long as some feel badly off, and others have morality-based reasons to oppose enforcement, the majority may oppose enforcement. In other words, if a significant minority of citizens in a country oppose enforcement on self-interested grounds, and a significant minority oppose enforcement on moral grounds, and the two groups are not coextensive, then a majority of citizens may oppose enforcement. If so, reduced enforcement may be a politically feasible policy.

The above is not intended to establish what most citizens will certainly support or what is certainly politically feasible to enact. It may be that most citizens ultimately have an interest in continuing current levels of enforcement despite the 
costs this entails. My point is merely that we cannot yet conclude, as Betts does, that the only way to admit dramatically more refugees into wealthy countries is to persuade most citizens that this is "the morally right thing to do" (Betts, p. 49). Morality is not all that matters: citizens who are not driven by moral arguments might feel they have self-interested reasons to admit more refugees. The question, then, is whether these reasons are common enough to lead to policy changes, and whether citizens can be persuaded to support these policy changes, at least compared to alternative changes. Further social science research can help answer this question, a possibility I will now address.

\section{Evaluating Relative Feasibility}

As noted earlier, Betts holds that a development-based approach is more feasible than admitting a significantly greater number of refugees into wealthy countries (p. 358). Importantly, he clarifies that this is a claim about the present: while in the future admitting more refugees might be possible, it is not possible today (p. 62).

Yet, the same claim could be made about the development policy Betts endorses. Betts suggests that today wealthy states have yet to donate the necessary up-front costs for ensuring stronger macroeconomic conditions in refugee-hosting poorer countries. They donate money, but not nearly enough to truly transform the local economies where most refugees live (Betts, pp. 271 and 349). Wealthy states invest heavily in border control at home and abroad rather than aid to assist refugees in becoming self-sufficient in poorer countries. Further, while helping refugees become self-sufficient in other countries might deter onward migration, as demonstrated in his analysis of data from Kenya (pp. 95-101), the evidence globally is mixed. As he notes, emigration in general increases as a state's GDP per capita increases, only decreasing once a country reaches a GDP per capita of roughly $\$ 8,000$. More research on the effects of development on refugees' migration choices may yield similarly mixed results. Even if aid does deter migration to an extent, it might not deter it enough for states to feel sending aid is worthwhile. This is not a controversial claim, and one Betts himself emphasizes (p. 213).

Given the political challenges of any policy aiming to help most refugees, we need to conduct further social scientific research to establish which policy is relatively more feasible. While Betts provides compelling evidence of the necessary conditions for sending aid to improve refugee rights and well-being in low-income 
states, and the sorts of arguments that could persuade policymakers in wealthy states to provide more up-front aid to improve refugees' employment prospects in these states, what is equally needed is rigorous research evaluating what sorts of arguments will persuade voters and policymakers to endorse large-scale refugee admissions into wealthy countries.

For example, research might establish whether it is more likely that policymakers in wealthy countries will be persuaded to (a) send large amounts of aid to transform refugee economies in low-income countries, perhaps because this will decrease migration of refugees from these countries, and thus garner voter support in the next election; or (b) admit very large numbers of refugees into their countries because they believe this is necessary to protect voters' freedom or economic self-interests, and thus garner voter support in the next election.

To establish whether example (a) or example (b) is more likely, it is not enough to establish voters' interests; in the real world, voters often act contrary to their interests, or at least do not always support the party that will best protect their freedom and economic wellbeing. ${ }^{13}$ Instead, one must evaluate which sorts of voters' interests will spur actions from policymakers. Establishing this requires not only understanding what voters can be persuaded to support but also whether this support will be translated into policymakers implementing policies conducive to protecting refugees at home and abroad.

It is further worth noting that examples (a) and (b) need not be mutually exclusive-citizens may wish both to admit many more refugees and to send more aid. However, refugee advocates can only spend so much time trying to change voters' and policymakers' minds. It might turn out that lobbying for less harsh enforcement against refugees is a more effective use of their time than lobbying for the sort of aid that transforms the economies where most refugees live.

Importantly, it may be that citizens have reasons to oppose sending aid that are similar to reasons they have to oppose enforcement. In the same way that citizens sometimes feel wronged when enforcement targets refugees who share their ethnicity or religion, citizens might feel wronged when aid is sent to deter the entrance of refugees who share their ethnicity or religion. Hosein discusses such wrongs when addressing a proposed policy called "refugee quota trading." Refugee quota trading involves states agreeing to accept a quota of the world's refugees and then paying other states to accept all or part of this quota. Hosein and others argue that paying other states to host refugees is wrong if the motives are wrong: a country that pays another state to host refugees so that fewer nonwhite 
refugees arrive in their own territory sends a demeaning message both to these refugees and to the country's own nonwhite citizens (Hosein, p. 137). ${ }^{14}$ Although Betts's proposal is distinct from quota trading (p. 49) - in quota trading a country literally pays another state to host refugees, while his proposal entails states sending aid to reduce refugees' incentives to migrate-it, too, can be wrong when the motives for sending aid to protect refugees' rights abroad are xenophobic.

This is consistent with the claim that even a wrong policy could be justifiably supported by humanitarian organizations. If these organizations cannot stop the xenophobia or racism, and xenophobic or racist states support sending aid to develop refugees' abilities in poorer states, humanitarian organizations may be justified in accepting this aid, while making very clear they oppose the motives behind states' contributions. At least, they act justifiably if the aid is effective at helping refugees compared to alternative policies. The question, therefore, is whether such aid really is effective compared to alternative policies. Once again, further empirical research is necessary.

\section{Conclusion}

The above observations, it is worth noting, are only possible because Betts's book is exceptionally detailed, balanced, and honest. The book openly presents states' objectionable reasons for granting aid, even citing a Danish official explaining that aid is provided because of xenophobic biases (p. 246) and quoting an unnamed ambassador explaining that aid was "good for xenophobes" (p. 249). The book describes not only the uncomfortable truths behind states' motives for sending aid but also the challenges of enhancing refugee economies in lowincome countries. Betts's transparent evaluation of these hurdles might cause some readers to conclude that it is best to focus on helping refugees reach wealthy states. This conclusion would be unfounded. We ought to instead accept a more general conclusion: it is possible to strengthen the rights of refugees, but only if policies proposed account for political realities. Political realities matter both in wealthy states, as Cohen's book demonstrates, and in poorer states, including the remote regions where a significant portion of the world's refugees live. While citizens in wealthy states might feel that permitting more refugees to arrive would garner substantial benefits, as demonstrated by Kukathas, Hosein, and Cohen, they might feel helping refugees access employment and rights abroad 
is preferable. To establish what is politically popular or can become popular, we must look beyond what is ideal and account for the interests of those with more power to help those with less. This requires gathering evidence to understand the broader forces impacting citizens' and policymakers' opinions, and the conditions of the places where refugees live and work. A book like Betts's is easy to critique, precisely because its analysis is detailed enough to garner debate. Such debate is essential, given the current failures to empower the vast majority of refugees.

\section{NOTES}

${ }^{1}$ In particular, Betts focuses on the Bole Michael and Gofa Mebrat neighborhoods in Addis Ababa.

2 "Number of Migrants at US Border Hits New Record High," BBC, June 10, 2021, www.bbc.co. uk/news/world-us-canada- 57422618 .

${ }^{3}$ While Cherem argues that limiting the definition of "refugees" to those fleeing persecution helps the worst off, this has been refuted by philosophers noting that many fleeing extreme hunger and general violence are worse off than many fleeing persecution, and many fleeing extreme hunger and violence lack access to any form of protection other than that of international migration. See Max Cherem, "Refugee Rights: Against Expanding the Definition of a 'Refugee' and Unilateral Protection Elsewhere," Journal of Political Philosophy 24, no. 2 (2016), pp. 183-205; Chandran Kukathas, "Are Refugees Special?," in Sarah Fine and Lea Ypi, eds., Migration in Political Theory: The Ethics of Movement and Membership (Oxford: Oxford University Press, 2016), pp. 249-68; and Mollie Gerver, "Sufficiency, Priority, and Selecting Refugees," Journal of Applied Philosophy 37, no. 5 (November 2020), pp. 713-30.

${ }^{4}$ John Burnett, "Asylum-Seekers Are Entering the U.S. Again-but Many More Migrants Are Left Behind," NPR, March 6, 2021, www.npr.org/2021/03/06/973824927/asylum-seekers-are-enteringthe-u-s-again-but-many-more-migrants-are-left-behind.

${ }^{5}$ Of course, the analogy is imperfect: today the United States has various civil rights protections for citizens that it did not provide in the 1920s, and so current American citizens may be more reluctant to admit and grant citizenship to quite as many migrants as it did then; however, if current levels of xenophobia and racism are lower than they were in the 1920s, perhaps admitting and granting civil rights protections to many migrants would not be viewed as a "cost." In this sense, Cohen's claim that a pro-immigrant policy could be revived is reasonable.

${ }^{6}$ Serena Parekh, No Refuge: Ethics and the Global Refugee Crisis (Oxford: Oxford University Press, 2020), pp. $154-58$.

7 Ibid., pp. 12-31 and 151-76.

${ }^{8}$ Bryan Roberts, Gordon H. Hanson, Derekh Cornwell, and Scott Borger, "Analysis of Migrant Smuggling Costs along the Southwest Border" (working paper, Office of Immigration Statistics, Department of Homeland Security, November 2010), www.hsdl.org/?abstract\&did=13845.

${ }^{9}$ Michael Blake, "Immigration," in R. G. Frey and Christopher Heath Wellman, eds., A Companion to Applied Ethics (Malden, Mass.: Blackwell, 2002), pp. 224-37; and José Jorge Mendoza, "Discrimination and the Presumptive Rights of Immigrants," in "Xenophobia and Racism," special issue, Critical Philosophy of Race 2, no. 1 (2014), pp. 68-83.

${ }^{10}$ Amy Reed-Sandoval, Socially Undocumented: Identity and Immigration Justice (Oxford: Oxford University Press, 2020).

${ }^{11}$ Mendoza, "Discrimination and the Presumptive Rights of Immigrants"; and Amy Reed-Sandoval, "Deportations as Theaters of Inequality," Pacific Philosophical Quarterly 29, no. 2 (April 2015), pp. 201-15.

${ }_{12}$ Reed-Sandoval, Socially Undocumented.

${ }^{13}$ Importantly, the parties often do not respond to voters' preferences, and perhaps mostly ignore or shape these preferences. See Christopher H. Achen and Larry M. Bartels, Democracy for Realists: Why Elections Do Not Produce Responsive Government (Princeton, N.J.: Princeton University Press, 2016).

${ }^{14}$ Mollie Gerver, "Moral Refugee Markets," in "Debating Asylum and Refuge," special issue, Global Justice 11, no. 1 (November 2018), pp. 45-63, at p. 51. 
Abstract: Some policies are not politically feasible. In the context of refugees, many claim it is not politically feasible to start admitting significantly more refugees into wealthy countries. In particular, it is not feasible for advocates of refugees to successfully persuade policymakers to adopt such a policy. A recent book by Alexander Betts argues that advocates should instead focus on developing the economies of lower-income countries where most refugees reside. This review essay argues that current data does not yet establish whether Betts's approach is more feasible than increasing refugee admissions to wealthy states. There are good reasons to suppose increasing refugees' admissions to wealthy states is politically feasible, if we account for the ways citizens in wealthy states are harmed when refugees are not admitted, and for the ways citizens are harmed when immigration enforcement prevents refugees from arriving. Drawing on recent books on immigration, this essay demonstrates that enforcement against refugees constrains citizens' freedom, well-being, and ability to hold their government to account. Further research can establish if citizens' interest in reducing enforcement can be translated into policy changes that significantly increase the number of refugees admitted. Such research is necessary before concluding that only helping refugees in lower-income countries is feasible.

Keywords: development, refugees, aid, immigration enforcement, migration 